\title{
PERENCANAAN INSTALASI SISTEMAIR CONDITIONERTIPE VRFPADA GEDUNG PERKANTORAN ENAM LANTAI UNTUK MENDUKUNG PROGRAM GREEN BUILDING
}

\author{
Riki Candra Putra, Muhammad Abrar \\ Program Studi Teknik mesin, Fakultas teknik, Universitas Muhammadiyah Tangerang, \\ Jl. Perintis Kemerdekaan I, No.33, Cikokol, Tangerang, Banten 15118, Indonesia \\ Email :riki.candra@gmail.com dan abrarkm19@gmail.com
}

\begin{abstract}
ABSTRAK
Kenyamanan dalam suatu ruangan diperkantoran atau rumah, merupakan kebutuhan, terutama di Indonesia yang memiliki iklim tropis (panas). Karena itu sistem pendingin udara atau sistem tata udara (sistem AC) telah menjadi kebutuhan di gedung-gedung perkantoran, oleh karena itu pengaturan atau perencanaan penempatan Air Conditioner (sering disebut sebagai AC) dalam sistem atau mekanisme bangunan atau gedung yang dirancang untuk kelembapan (dehumidify). Karena AC adalah barang mewah dan mahal maka konsep Green Building hadir dan menjadi suatu kebutuhan ditengah fenomena global warming dan isu kerusakan lingkungan yang sedang melanda bumi, untuk perencanaan instalasi AC di gedung perkantoran enam lantai di Jakarta menggunakan sistem VRF (Variable Refrigerant Flow) dengan teknologi yang sudah dilengkapi dengan CPU dan kompresor inverter dan sudah terbukti menjadi handal, efisiensi energi, berbeda dengan pendahulunya (Single Split, Split Duct, dll). Sistem VRF merupakan suatu teknologi pengaturan kapasitas AC yang memiliki kemampuan untuk mencegah pendinginan yang berlebih pada suatu ruangan, sehingga dapat menghemat listrik, juga memiliki tingkat kebisingan yang rendah dan hemat tempat karena dapat menggunakan satu kondensor untuk mensuplai beberapa evaporator, serta dapat mengatur jadwal dan temperatur AC yang diinginkan secara terkomputerisasi.
\end{abstract}

Kata Kunci: Air Conditioner, VRF, HVAC, AC Split, Green building

\section{PENDAHULUAN}

Air conditioner atau yang lebih dikenal dengan $\mathrm{AC}$ merupakan alat pendingin ruangan yang sering digunakan baik di rumah tangga maupun di instansi pemerintah maupun swasta.AC merupakan sebuah alat penyejuk ruangan yang mampu mengkondisikan udara dalam ruangan serta memberikan efek nyaman bagi tubuh (Sofyan, 2010). Saat ini pada gedung bertingkat selain menggunakan AC split standar namun ada beberapa gedungyang juga menggunakan AC tipe VRF (Variable Refrigerant Flow) dalam mencanangkan konsep green building untuk meningkatkan konsep gedung yang rendah konsumsi energi, rendah emisi dan kualitas lingkungan di dalam ruangan yang baik.

Green building adalah konsep untuk 'bangunan berkelanjutan' dan mempunyai syarat tertentu, yaitu lokasi, sistim perencanaan dan perancangan, renovasi dan pengoperasian, yang menganut prinsip hemat enrgi serta harus berdampak positif bagi lingkungan, ekonomi dan sosial. Dengan definisi lain Green Building adalah bangunan dimana sejak dimulai dalam tahap perencanaan, pembangunan, pengoperasian hingga dalam operasional pemeliharaannya memperhatikan aspek-aspek dalam melindungi, menghemat, mengurangi penggunaan sumber daya alam, menjaga mutu dari kualitas udara di dalam ruangan, dan memperhatikan kesehatan penghuninya yang semuanya berpegang kepada kaidah bersinambungan.

Kita ketahui bahwa penggunaan AC split standar seringkali menimbulkan dampak negatif pada lingkungan, salah satunya adalah karena konsumsi daya listrik yang besar, konfigurasi outdoor yang banyak (mengikuti jumlah ruangan yang ingin dipasang AC) dan biaya perawatan yang besar sehingga konsep 
green building yang diwacanakan oleh pemerintah menjadi kurang dari yang diharapkan, yaitu kualitas udara, kenyamanan ruangan dan biaya listrik yang besar. Penelitian yang dilakukan Utomo dan Andini (2014) di salah satu rumah sakit swasta di Surabaya menyatakan bahwa penelitian tentang green building dipengaruhi diantaranya oleh penggunaan AC VRF, namun penggunaan AC VRF memerlukan biaya investasi yang lebih besar dibandingkan dengan penggunaan $\mathrm{AC}$ standar.

Saat ini konsep green building hadir dan menjadi suatu kebutuhan ditengah fenomena global warming dan isu kerusakan lingkungan yang sedang melanda bumi. Data dari hasil studi Masyarakat Ekonomi ASEAN (MEA), menunjukan bahwa bangunan berpotensi memberikan dampak pada kerusakan lingkungan yaitu kerusakan lingkungan yang berhubungan dengan green building. Green building didefinisikan sebagai sebuah perencanaan dan perancangan melalui sebuah proses yang kan memperbaiki lingkungan dan mengunakan sumber daya secara efisien pada seluruh siklus hidup bangunan dari mulai pengolahan tapak, perancangan, pembangunan, penghunian, pemeliharan, renovasi dan perubahan bangunan.

Dari salah satu konsep green building yaitu pada green technology diwujudkan dengan penggunaan alat-alat penunjang untuk mencapai konsep green building seperti AC VRF yang dibandingkan dengan AC standar. Dan ditinjau dari beban pendinginan pada green building sudah mempunyai desain ruangan dan material yang memiliki syarat yang memenuhi standar green building. Oleh karena itu desain ruangan dan material sangat mempengaruhi besar beban pendinginan yang akan dibuang oleh AC, dimana AC VRF yang akan dibahas pada penulisan ini merupakan jenis AC yang bisa mengontrol temperature, kelembaban setiap unit indoor.

Berdasarkan tulisan dari Vicky Bertolini, Wisnumurti dan Achfas Zacoeb pada perbandingan tiga jenis $\mathrm{AC}$ untuk mendapatkan value engineering pada pembangunan gedung, dibandingkan dengan AC konvensional dan AC Inverter, AC VRF memiliki penghematan sebesar $10.80 \%$ untuk pemakaian AC selama 10 tahun, meskipun biaya awal AC VRF investasinya besar tetapi biaya operasional dan biaya perawatan mempunyai urutan yang paling rendah dibandingkan kedua AC diatas.

Dari segi instalasi AC VRF mempunyai tingkat pemasangan yang lebih mudah dibandingkan $\mathrm{AC}$ standar. Oleh karena itu pada perlu untuk ditinjau bagaimana instalasi dan besar beban pendinginan yang efisien untuk sistem VRF, pada tulisan ini diambil kasus instalasi AC VRF pada gedung perkantoran enam lantai dalam menerapkan konsep green building.

\section{TINJAUAN PUSTAKA}

AC (Air Conditioner) sudah dimulai sejak jaman Romawi yaitu dengan membuat penampung air yang mengalir di dalam dinding rumah sehingga menurunkan suhu ruangan, tetapi saat itu hanya orang tertentu saja yang bisa karena biaya membangunnya sangatlah mahal karena membutuhkan air dan juga bangunan yang tidak biasa, hanya para raja dan orang kaya saja yang dapat membangunnya. Tahun 1820 ilmuwan Inggris bernama Michael Faraday menemukan cara baru mendinginkan udara dengan menggunakan Gas Amonia dan pada tahun 1842 seorang dokter menemukan cara mendinginkan ruangan di Rumah Sakit Apalachicola yang berada di Florida Ameika Serikat. Dr.Jhon Gorrie adalah yang menemukannya dan ini adalah cikal bakal dari tehnologi AC (air conditioner) tetapi sayangnya sebelum sempurna beliau sudah meninggal pada tahun 1855 .

Willis Haviland Carrier seorang Insinyur dari New York Amerika menyempurnakan penemuan dari Dr. Jhon Gorrie tetapi AC ini digunakan bukan untuk kepentingan atau kenyamanan manusia melainkan untuk keperluan percetakan dan industrylainnya. Penggunaan AC untuk perumahan baru dikembangkan pada tahun 1927 dan pertama dipakai disebuah rumah di Mineapolis, Minnesota. Penggunaan AC saat ini sudah digunakan disemua sektor, tidak hanya industri saja tetapi juga sudah di perkantoran dan perumahan dengan berbagai macam bentuk dari mulai yang besar hingga yang kecil, semuanya masih berfungsi sama yaitu untuk mendinginkan suhu ruangan agar orang merasa nyaman.

Salah satu jenis AC yang ada adalah AC VRF (Variable Refrigerant Flow). AC VRF adalah unit AC yang mempunyai bermacam-macam laju aliran refrijeran pada 
tiap-tiap saluran di dalam ruangan (indoor), AC VRF hanya mempunyai satu unit outdoor tetapi dapat mempunyai lebih dari satu atau banyak unit indoor.

Sistem VRV atau VRF (variable refrigerant flow) yang telah diperkenalkan di Jepang lebih dari 20 tahun yang lalu, dan menjadi sangat popular dibanyak negara. Teknologi ini secara bertahap diperluas pemasarannya dan menjangkau benua Eropa pada tahun 1987, dan terus meningkatkan pangsa pasarnya diseluruh dunia. Di Jepang sendiri, sistem ini penggunaannya sekitar $50 \%$ dari ukuran medium gedung komersial (sampai $6500 \mathrm{~m}^{2}$ ) dan sepertiga dari gedung komersial yang besar (lebih dari $6500 \mathrm{~m}^{2}$ ).

Sistem konvensional membuang udara dari ruangan yang diserap oleh refrigerant dengan cara mensirkulasikan udara (pada sistem $d u c t$ ) atau air (pada chiller) ke seluruh bangunan. Sistem VRF keunggulannya adalah dalam hal kapasitas yang lebih besar, versi yang lebih rumit dalam sistem multisplit dengan penggunaan duct yang lebih sedikit, dengan kemampuan tambahan dari hubungan antara duct dengan fan coil unit.

Sistem ini membutuhkan banyak evaporator dan pengaturan refrigerant yang rumit serta untuk sistem kontrolnya.Sistem ini juga memerlukan sistem saluran udara yang terpisah.Istilah variable refrigerant mengacu pada kemampuan sistem untuk mengontrol jumlah refrigerant yang mengalir ke masingmasing evaporator. Hal ini memungkinkan penggunaan banyak evaporator dengan kapasitas yang berbeda-beda.

\section{Macam-macam beban pendinginan}

Beban panas yang menjadi beban pendinginan umumnya berasal dari bermacammacam sumber yang berbeda. Adapun sumber panas yang umum adalah:

1. Panas yang berasal dari sisi luar dinding berisolasi transparan (melalui konduksi).

2. Panas yang masuk melalui kaca atau bahan-bahan transparan (melalui radiasi).

3. Panas yang dibawa udara dari luar ruang pendingin.

4. Panas yang berasal dari produk/bendabenda yang didinginkan.

5. Panas yang berasal dari pekerja /operator.

6. Panas yang berasal dari peralatan yang di simpan di dalam ruangan seperti motor listrik, lampu, peralatan listrik lainnya.
Faktor perpindahan panas melalui dinding (wall gain load)

Jumlah beban panas yang dipindahkan melalui bidang ruangan pendingin tiap satuan waktu merupakan fungsi dari 3 faktor dari persamaan berikut:

$$
\mathrm{Q}=\mathrm{A} \cdot \mathrm{U} \cdot \Delta \mathrm{t}
$$

Dimana:

$\mathrm{Q}=$ jumlah panas yang dipindahkan (BTU/jam)

$\mathrm{A}=$ luas permukaan dinding bagian dalam $\left(\mathrm{ft}^{2}\right)$ $\mathrm{U}=$ angka koefisien perpindahan panas (BTU/jam $/{ }^{\circ} \mathrm{F} / \mathrm{ft}^{2}$ )

$\Delta \mathrm{t}=$ perbedaan temperatur diantara dinding $\left({ }^{\circ} \mathrm{F}\right)$

\section{Penggunaan faktor keselamatan (safety faktor)}

Jumlah total beban pendinginan untuk waktu 24 jam adalah jumlah dari semua jenis beban panas. Untuk pengamanan ditambahkan $5 \%$ sampai dengan $10 \%$.Besarnya persentasi ini tergantung dari tingkat kepercayaan atas informasi yang digunakan pada saat mengadakan perhitungan sebelumnya, biasanya diambil $10 \%$.

\section{Kalor Sensibel dan Kalor Latent}

Beban kalor pendinginan/pemanasan untuk sebuah ruangan terdiri dari dua komponen :

Kalor Sensibel : adalah kalor yang dapat diukur, kalor yang menyebabkan terjadinya kenaikkan/penurunan temperatur. beban panas yang dipengaruhi oleh perbedaan suhu, seperti beban panas yang lewat kontruksi bangunan, peralatan elektronik, lampu, dll.

Contoh beban sensibel : beban kalor melalui dinding, atap, langit-langit, lantai, peralatan listrik (komputer dan lampu) karena beban infiltrasi ruangan. Dinding yang terbuat dari bahan triplek dan kaca tidak terdapat beban kalor karena tidak terkena panas radiasi matahari.

Kalor latent : Kalor laten adalah kalor yang diperlukan untuk merubah phasa benda, mulai dari titik lelehnya atau titik didihnya atau titik bekunya sampai benda itu berubah phasa secara sempurna, tetapi temperaturnya tetap dan dipengaruhi oleh adanya perbedaan kelembaban udara.

Contoh beban latent : penghuni (orang) dan beban kalor pada infiltrasi ruangan. 


\section{METODOLOGI PENELITIAN}

Pada penelitian ini dilakukan metode mengikuti aliran chart sebagai berikut:

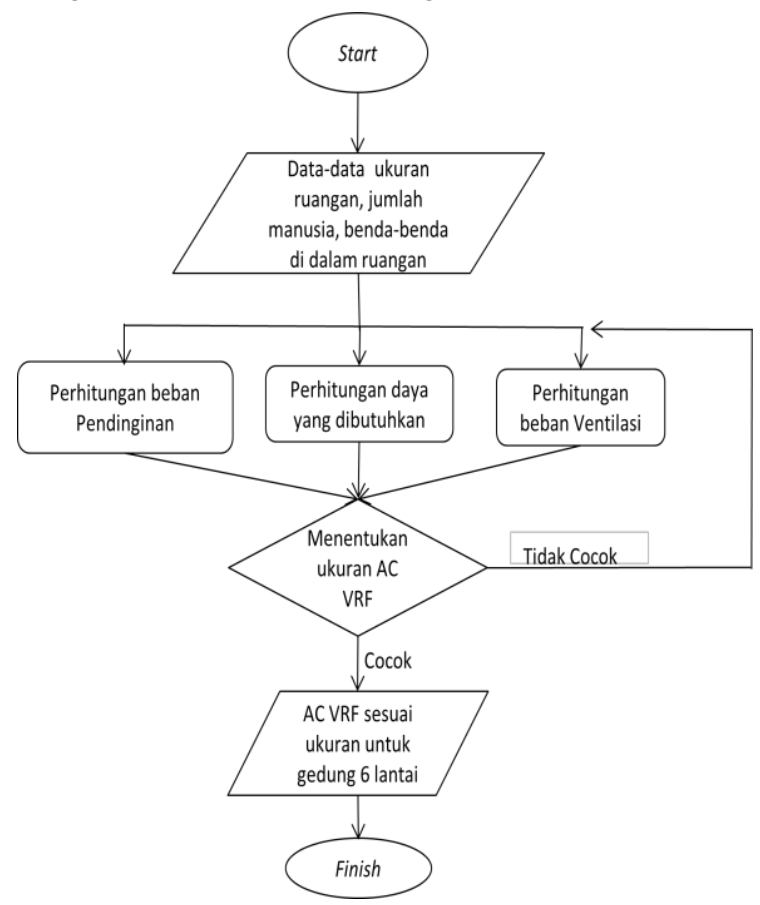

Gambar 1. Flow Chart Penelitian

Tempat penelitian dilakukan pada gedung perkantoran enam lantai dengan Posisi : -06 ${ }^{\circ}-19^{\prime}$ (Lintang Selatan), 106 - 83' (Bujur Timur), Kecepatan angin : $6.4 \mathrm{~km}$ per jam, Elevasi : $13 \mathrm{~m}$ di atas permukaan laut.

Penelitian dilakukan di salah satu perusaahan konsultan di wilayah Jakarta. Peneliti melakukan pengumulan data primer, yaitu merupakan sumber data yang diperoleh secara langsung dari sumber asli dari pihak pertama, dari angka yang diperoleh akan dianalisis data. Metode Pengumpulan data ini diambil dari data teknik luasan bangunan pada setiap lantai dan ruangan proyek gedung perkantoran enam lantai.

Teknik pengumpulan data sangat ditentukan oleh metodologi penelitian. Penelitian kuantitatif dikenal teknik pengumpulan data: angket (questionnaire), wawancara, dan dokumentasi. Teknik pengumpulan data yang peneliti gunakan adalah dokumentasi. Peneliti melakukan analisis data pada pencatatan atau pelaporan hasil pengerjaan pemasangan $\mathrm{AC}$.

\section{Kriteria Tempat Penelitian}

- Ketentuan dan Standarisasi
Acuan peraturan yang digunakan :

1) Peraturan Pemda DKI

Tentang $\rightarrow$ Bangunan diwilayah Propinsi Daerah khusus ibukota Jakarta.

a) Paragraf $\rightarrow$ Instalasi tata udara dalam bangunan

2) KEPMEN PU No. 28 Tahun 2008, BAB V sistem proteksi aktif poin 5.8 hal 195 tentang $\rightarrow$ Ventilasi Mekanik dan Sistem Pengendalian Asap.

3) Standard yang digunakan :

a) SNI-03-6571-2001 $\Rightarrow$ Sistem Pengendalian Asap Kebakaran pada Bangunan Gedung.

1) Pasal $5 \Rightarrow$ Sistem Pengendalian Asap dan Penerapannya.

2) Pasal $5.3 \Rightarrow \quad$ Sistem Pressurisasi Tangga Kebakaran.

b) SNI-03-6572-2001 $\Rightarrow$ Tata Cara Perancangan Sistem Ventilasi dan Pengkondisian Udara.

c) SNI-03-6390-2000 $\Rightarrow$ Konservasi Energi Sistem Tata Udara.

- Pasal $8.1 \Rightarrow$ Sistem dan Peralatan Tata Udara yang Sederhana.

d) ASHRAE 62-2001 $\Rightarrow$ Indoor Air Quality.

- Pasal 6.1.3 $\Rightarrow$ Ventilation Requirements.

e) SMACNA HVAC Duct Construction standard First Edition 1985.

f) NFPA 90A $\Rightarrow$ Standard for Installation Air Conditioning\&Ventilating System.

g) UL555 / UL555S $\Rightarrow$ Standard for Safety Fire Damper 1999.

h) AMCA-210-74 $\Rightarrow$ Fan Performance Testing Standard.

i) Persyaratan Umum Instalasi Listrik (PUIL) 2000 PUIL 2000 (Peraturan Umum Instalasi Listrik).

\section{PENGOLAHAN DATA DAN PEMBAHASAN}

A. Menghitung beban pendingin

Dalam menghitung beban pendingn, kita dapat menggunakan data luasan yang telah dihitung pada proses perhitungan luasan tadi. Setiap ruangan mempunyai luas dan fungsi yang berbeda - beda, maka dari itu kebutuhan pendingin (AC) atupun ventilasi pada setiap ruangan pastinya berbeda. Sebagai contoh cara menghitung kebutuhan pendingin 
(AC) dan Ventilasi, akan penulis jabarkan rumus dan perhitungannya sebagai berikut :

a. Menghitung kebutuhan pendingin (AC)

Misalkan kita ambil contoh ruangan Office

\& pada lantai 5 .

Diketahui :

- Luas ruangan $=270 \mathrm{~m}^{2}$

- Jumlah orang yang menempati ruangan =

34 orang

- Beban pendingin menurut fungsi ruangan

$=17 \mathrm{~m}^{2} / \mathrm{TR}$

- Airflow multiply $=292,96$ (konversi TR ke CFM)

Penyelesaian :

Kepadatan ruangan $=$ luas $/$ jumlah orang

$=270 / 34=7,9$

Jadi kepadatan ruangan $=8 \mathrm{~m}^{2} /$ orang .

Beban pendingin $=$ Luas/beban pendingin fungsi ruangan

$$
=270 / 17 \mathrm{~m}=15,88
$$

TR

(konversikan ke british)

$$
=15,88 \times 12000=190560 \mathrm{Btu} / \mathrm{h}
$$

(dimana : $1 \mathrm{TR}=12000 \mathrm{Btu} /$ hour)

$$
=190560 \mathrm{Btu} / \mathrm{h}=55.8 \mathrm{~kW}
$$

(dimana : $1 \mathrm{Btu} / \mathrm{h}=0.0029 \mathrm{~kW})$

$$
=190560(\mathrm{Btu} / \mathrm{h}) / 270 \mathrm{~m}^{2}=706 \mathrm{Btu} / \mathrm{m}^{2}
$$

Airflow $=15,88 \times 292,56=4,653 \mathrm{cfm}$.

Fresh air $=$ Airflow $\times 0,15$

$$
=4,653 \times 0,15=698 \mathrm{cfm}
$$

B. Menghitung kebutuhan ventilasi

Kebutuhan ventilasi biasanya diberikan pada ruangan toilet, gudang, dsb. Kali ini saya akan ambil contoh menghitung kebutuhan ventilasi pada toilet office lantai dasar. Perhitungannya adalah sebgai berikut :

Diketahui :

- Luas toilet $=34 \mathrm{~m}^{2}$

- Tinggi toilet $=3,5 \mathrm{~m}$

- Konversi $\mathrm{cfm} \mathrm{ke} \mathrm{cmh}=1 \mathrm{cfm}=0,589 \mathrm{cmh}$ Penyelesaian :

Airflow $=$ Luas $\times$ Tinggi $\mathrm{x} 15 \times 0,589$

$$
=34 \times 3,5 \times 15 \times 0,589=1051 \mathrm{cfm}
$$

Sebelum menghitung beban pendingin, terlebih dahulu ditentukan temperature ruangan yang diinginkan kriteria temperatur ruangan berdasarkan tempat, dapat dilihat pada tabel berikut:
Tabel 1 Kriteria temperatur ruangan berdasarkan tempat

\begin{tabular}{|l|c|c|}
\hline \multirow{2}{*}{ Description } & Temperature & Rel. Humidity \\
\cline { 2 - 3 } & $\left({ }^{\circ} \mathrm{C}\right) \mathrm{DB}$ & $\% \mathrm{RH}$ \\
\hline Lounge & $28,5^{\circ} \pm 1,5$ & $60 \pm 10 \%$ \\
\hline Lobby lift & $28,5^{\circ} \pm 1,5$ & $60 \pm 10 \%$ \\
\hline $\begin{array}{l}\text { Meeting } \\
\text { Room }\end{array}$ & $25,5^{\circ} \pm 1,5$ & $60 \pm 5 \%$ \\
\hline Office & $25,5^{\circ} \pm 1,5$ & $60 \pm 5 \%$ \\
\hline $\begin{array}{l}\text { Function } \\
\text { Room }\end{array}$ & $25,5^{\circ} \pm 1,5$ & $60 \pm 5 \%$ \\
\hline
\end{tabular}

Setelah menghitung kebutuhan beban

\begin{tabular}{|c|c|c|c|c|c|}
\hline \multirow[b]{2}{*}{ Lantai } & \multirow[b]{2}{*}{ Area-area (rooms) } & \multirow{2}{*}{$\begin{array}{l}\text { Total } \\
\text { Area } \\
(\mathrm{m} 2)\end{array}$} & \multicolumn{3}{|c|}{ Total Beban Pendinginan } \\
\hline & & & (TR) & $\left(\mathrm{Btu} / \mathrm{m}^{2}\right)$ & (Btu/h) \\
\hline 1 & $\begin{array}{l}\text { SECURITY, LOBBY \& OFFICE BOY } \\
\text { ROOM }\end{array}$ & 49 & 2.54 & 1212 & 30,480 \\
\hline 2 & $\begin{array}{l}\text { OFFICE LOBBY, RECEPTION / } \\
\text { LOUNGE, MEETING ROOM-01, } \\
\text { MEETING ROOM-02, MEETING } \\
\text { ROOM-03, HRD, IT, SERVER ROOM, } \\
\text { TECHNICIAN OFFICE \& MODEL } \\
\text { DISPLAY B }\end{array}$ & 253.7 & 16.3 & 8502 & 195,600 \\
\hline 3 & $\begin{array}{l}\text { LIFT LOBBY, MEETING TRAIDING, } \\
\text { TRAIDING, FILLING FINANCE, } \\
\text { DIRECTOR-1, DIRECTOR-2, } \\
\text { FINANCE, MEETING ROOM-4, } \\
\text { CASHIER LOCKET ROOM, WAITING } \\
\text { ROOM, \& MODEL DISPLAY AREA }\end{array}$ & 265 & 15.8 & 8636 & 189,600 \\
\hline 4 & $\begin{array}{l}\text { LIFT LOBBY, LOUNGE, LEGAL } \\
\text { OFFICE, SECRETARY OFFICE, \& } \\
\text { PRESIDENT DIRECTOR }\end{array}$ & 291 & 16.7 & 3334 & 200,400 \\
\hline 5 & LIFT LOBBY, LOUNGE, \& OFFICE & 338 & 19.3 & 1873 & 231,600 \\
\hline 6 & LIFT LOBBY \& LOUNGE & 198 & 21.2 & 1912 & 254,400 \\
\hline & Total & 1394.7 & 91.84 & 25469 & 1102080 \\
\hline
\end{tabular}
pendingin untuk semua ruangan, maka data

\begin{tabular}{|c|c|c|c|c|c|}
\hline \multirow[b]{2}{*}{ Lantai } & \multirow[b]{2}{*}{ Area-area (rooms) } & \multirow[b]{2}{*}{$\begin{array}{l}\text { Total } \\
\text { Area } \\
(\mathrm{m} 2)\end{array}$} & \multicolumn{3}{|c|}{ Beban Ventilasi } \\
\hline & & & $\begin{array}{l}\text { Wtr. } \\
\text { Flow } \\
\text { (gpm) }\end{array}$ & $\begin{array}{l}\text { Air Flow } \\
\text { (cfm) }\end{array}$ & $\begin{array}{c}\text { Fresh } \\
\text { Air } \\
(\mathrm{cfm})\end{array}$ \\
\hline 1 & $\begin{array}{l}\text { SECURITY, LOBBY \& OFFICE BOY } \\
\text { ROOM }\end{array}$ & 49 & 6.08 & 743 & 111 \\
\hline 2 & $\begin{array}{l}\text { OFFICE LOBBY, RECEPTION / } \\
\text { LOUNGE, MEETING ROOM-01, } \\
\text { MEETING ROOM-02, MEETING } \\
\text { ROOM-03, HRD, IT, SERVER ROOM, } \\
\text { TECHNICIAN OFFICE \& MODEL } \\
\text { DISPLAY B }\end{array}$ & 253.7 & 39.18 & 4,783 & 717 \\
\hline 3 & $\begin{array}{l}\text { LIFT LOBBY, MEETING TRAIDING, } \\
\text { TRAIDING, FILLING FINANCE, } \\
\text { DIRECTOR-1, DIRECTOR-2, FINANCE, } \\
\text { MEETING ROOM-4, CASHIER LOCKET } \\
\text { ROOM, WAITING ROOM, \& MODEL } \\
\text { DISPLAY AREA }\end{array}$ & 265 & 4.5 & 6,480 & 964 \\
\hline 4 & $\begin{array}{l}\text { LIFT LOBBY, LOUNGE, LEGAL OFFICE, } \\
\text { SECRETARY OFFICE, \& PRESIDENT } \\
\text { DIRECTOR }\end{array}$ & 291 & 2.7 & 4909 & 736 \\
\hline 5 & LIFT LOBBY, LOUNGE, \& OFFICE & 338 & 46.25 & 5646 & 847 \\
\hline 6 & LIFT LOBBY \& LOUNGE & 198 & 50.8 & 6201 & 930 \\
\hline & Total & 1394.7 & 149.51 & 28762 & 4305 \\
\hline
\end{tabular}
yang didapat dari hasil perhitungan tadi seperti yang terlampir pada tabel-tabel dibawah ini:

Tabel 2 Total Kebutuhan beban pendingin dan ventilasi untuk semua ruangan 
Kemudian berdasarkan jumlah beban pendinginan yang sudah dikumpulkan di atas dapat diuraikan lagi menjadi jenis beban pendinginan latent dan sensibel :

Tabel 3 Beban pendinginan latent dan sensibel

\begin{tabular}{|c|c|c|c|}
\hline Lantai & Area-area (rooms) & $\begin{array}{c}\text { Q } \\
(\text { Btw/h) } \\
\text { Sensibel }\end{array}$ & \begin{tabular}{|c|} 
Q \\
(Btu/h) \\
Latent \\
\end{tabular} \\
\hline 1 & SECURITY, LOBBY \& OFFICE BOY ROOM & 23,165 & 7315.2 \\
\hline 2 & $\begin{array}{l}\text { OFFICE LOBBY, RECEPTION / LOUNGE, } \\
\text { MEETING ROOM-01, MEETING ROOM-02, } \\
\text { MEETING ROOM-03, HRD, IT, SERVER ROOM, } \\
\text { TECHNICIAN OFFICE \& MODEL DISPLAY B }\end{array}$ & 148,656 & 46944 \\
\hline 3 & $\begin{array}{l}\text { LIFT LOBBY, MEETING TRAIING, TRAIDING, } \\
\text { FILIING FINANCE, DIRECTOR-1, DIRECTOR-2, } \\
\text { FINANCE, MEETING ROOM-4, CASHIER } \\
\text { LOCKET ROOM, WAITING ROOM, \& MODEL } \\
\text { DISPLAY AREA }\end{array}$ & 144,096 & 45504 \\
\hline 4 & $\begin{array}{l}\text { LIFT LOBBY, LOUNGE, LEGAL OFFICE, } \\
\text { SECRETARY OFFICE, \& PRESDENT DIRECTOR }\end{array}$ & 152,304 & 48096 \\
\hline 5 & LIFT LOBBY, LOUNGE, \& OFFICE & 176,016 & 55584 \\
\hline 6 & LIFT LOBBY \& LOUNGE & 193,344 & 61056 \\
\hline & Total & 837580.8 & 264499.2 \\
\hline & Total Beban pendingin (sensibel+latent) & \multicolumn{2}{|c|}{$1102080 \mathrm{Btu} / \mathrm{h}$} \\
\hline & Safety factor $10 \%$ & \multicolumn{2}{|c|}{$110208 \mathrm{Btu} / \mathrm{h}$} \\
\hline & Grand total beban pendingin & \multicolumn{2}{|c|}{$1212288 \mathrm{Btu} / \mathrm{h}$} \\
\hline & Nilai beban pendingin (TR) & \multicolumn{2}{|c|}{101.02} \\
\hline & Nilai beban pendingin $(\mathrm{kW})$ & \multicolumn{2}{|c|}{355.29} \\
\hline & Nilai beban pendingin (HP) & \multicolumn{2}{|c|}{476.45} \\
\hline
\end{tabular}

\section{Pembahasan}

Prinsip kerja AC pada dasarnya penyerapan panas oleh evaporator, pemompaan panas oleh kompresor, pelepasan panas oleh kondensor serta proses ekspansi. Proses-proses ini berkaitan erat dengan temperatur didih dan temperatur kondensasi refrigerant. Refrigerant adalah zat yang mudah berubah bentuk (menjadi uap atau cair) sehingga cocok jika digunakan sebagai media pemindah panas dalam mesin pendingin.

Temperatur didih dan temperatur kondensasi berkaitan dengan tekanan.Titik didih dan titik embun dapat digeser naik atau main dengan mengatur besarnya tekanan yang diberikan. Hal ini berpengaruh besar terhadap proses perpindahan panas yang terjadi pada AC. Cara kerja AC pada mulanya terjadi perpindahan panas dari dalam ruangan ke luar ruangan. Kompresor yang berfungsi mengalirkan zat pendingin (refrigerant) ke dalam pipa tembaga yang berbentuk kumparan. Udara ditiupkan oleh kipas udara (blower atau fan) di sela-sela kumparan tadi, sehingga panas yang ada dalam udara diserap oleh pipa refrigerant dan kemudian mengembun. Udara yang melalui kumparan dan telah diserap panasnya, masuk ke dalam ruangan dalam keadaan sejuk/dingin. Selanjutnya udara dalam ruang dihisap dan selanjutnya proses penyerapan panas diulang kembali.

Alat pendingin sentral (VRF sytem) merupakan alat yang digunakan untuk mengkondisikan udara ruangan, dimana udara dingin dari alat tersebut dialirkan ke ruangan yang dikondisikan melalui saluran khusus (ducting). Bentuk dan cara pengoperasian dibuat sesederhana mungkin dengan memperhatikan keindahan dan kemudahan dalam perawatannya.

\section{Cerobong Aliran Udara}

Berdasarkan aliran udara (duct) dirancang berdasarkan metode "Equal Friction". Konstruksi cerobong udara dirancang untuk kecepatan udara didalam duct adalah kecepatan rendah, maximum $2000 \mathrm{fpm}$ atau max. tekanan dalam duct 3 inch WG. Berdasarkan kerugian tekanan sepanjang duct dipilih harga-harga sebagai berikut :

a. Cerobong distribusi udara suplai dari unit AC dengan kerugian tekanan 0,08 s/d 0,1 inch $W G$ per $100 \mathrm{ft}$. panjang duct.

b. Kerugian tekanan di terminal diffuser dengan $0,06 \mathrm{~s} / \mathrm{d}$ 0,15 inch WG.

c. Cerobong udara balik (return) direncanakan dengan kerugian tekanan sebesar $0,08 \mathrm{~s} / \mathrm{d}$ 0,1 inch WG per $100 \mathrm{ft}$.

d. Cerobong udara segar, exhaust basement, exhaust toilet direncanakan dengan kerugian tekanan 0,08 s.d 0,12 inch WG per $100 \mathrm{ft}$.

Air Cooled Split Variable Ref. : Split Duct, Ceilling Concealed menggunakan refrigerant R410A

Pipa Refrigerant : Copper tube type hard drawn / ASTM B280

Pipa drain : PVC Class AW

\section{Pekerjaan Ducting}

Lembaran Metal : Lembaran plat baja lapis seng (BJLS) kualitas Lock forming Bending test 0 .

Standar : SMACNA

\section{Pekerjaan Isolasi}

Isolasi Ducting : Glasswool density $24 \mathrm{~kg} / \mathrm{m}^{3} \mathrm{k}$ value $0,26 \mathrm{BtuH} /{ }^{\circ} \mathrm{F}$. Sqft with 
alluminium foil vapour barrier, DSFR.

Isolasi Pipa : Closed Cell, Elastomeric Nitrile Rubber, density $80 \mathrm{~kg} / \mathrm{m} 3$

Fan : Axial Fan, Wall Fan.

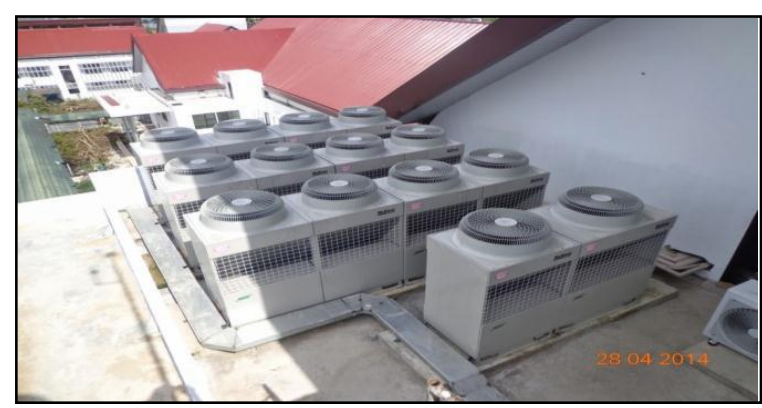

(a)

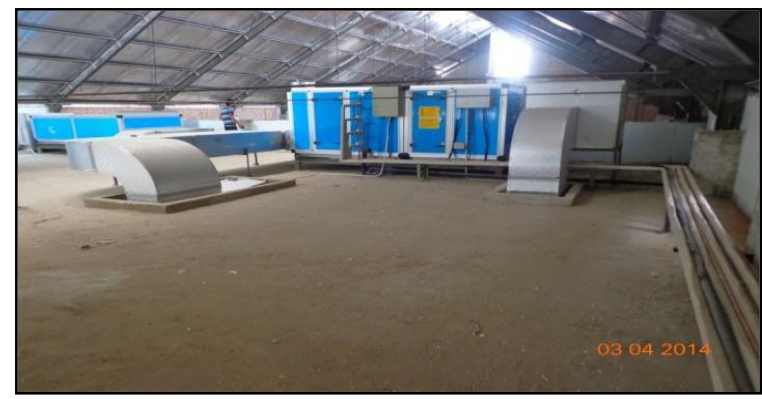

(b)

Gambar 2 AC VRF (a) Outdoor dan (b) Indoor

\section{KESIMPULAN DAN SARAN}

\section{Kesimpulan}

Bangunan suatu gedung terdiri dari 3 komponen penting, yaitu struktur, arsitek dan utilitas atau yang dikenal juga dengan istilah ME (Mekanikal dan Elektrikal) di gedung. Ketiganya satu sama lain saling terkait. Jika struktur mengedepankan kekuatan, arsitek lebih menekankan pada keindahan, maka ME (Mekanikal \& Elektrikal) lebih mengedepankan pada fungsi. Sekuat apapun bangunan atau seindah apapun bangunan, jika tidak ditunjang dengan suatu sistem mekanikal \& elektrikal, maka bangunan tersebut tidak ada fungsinya. Jadi sangat jelas antara ketiga komponen dalam suatu gedung yang saling terkait satu sama lain.

Dengan demikian sistem mekanikal \& elektrikal termasuk salah satu komponen yang sangat penting. Jadi intinya suatu bangunan yang telah dirancang oleh para arsitek akhirnya harus dipakai, dihuni dan dinikmati. Untuk itu bangunan harus dilengkapi dengan prasarana yang sesuai dengan kebutuhan gedung / perkantoran itu sendiri. Setiap gedung oleh perancangnya dimungkinkan dikonsep dalam suatu paradigma tersebut. Dan konsep mekanikal dan elektrikal untuk memenuhi sesuai dengan fungsinya.

\section{Saran}

Dalam melakukan perencanaan disarankan agar adanya koordinasi yang baik antrar pihak sipil arsitek dan ME dari suatu proyek agar benar-benar memperhatikan masalah yang ada dan bisa lebih tepat dalam melakukan perencanaan yang akan dilakukan. Dalam melakukan perencanaan, harus disesuaikan dengan permintaan owner dan mengacu kepada standarisasi yang ada.

\section{DAFTAR PUSTAKA}

1. W. Goetzler, M. Guernsey, J. Young, J. Fuhrman, O. Abdelaziz, PhD. The Future of Air Conditioning for Buildings. U.S. Department of Energy. Navigant Consulting, Inc. \& Oak Ridge National Laboratory. July 2016

2. Shaik Gulam Abul Hasan, Syeda Saniya Fatima, Ganoju Sravan Kumar. Design Of a VRF Air Conditioning System With Eenergy Conservation On Commercial Building. IJESRT-Journal. Mehanical department, MGIT. ISSN: 2277-9655. July, 2015

3. Kartik M. Patel, Pushpendra K. Jain Prof., Dinesh K. Koli Prof. Design of HVAC with VRF System for a Space House in Ahmedabad. Department of Mechanical Engineering, University Bhopal MP. India. IJSTE-Journal. Volume 1, Issue 10. ISSN (online): 2349-784X. April 2015

4. Sudarwani Maria M. Penerapan Green Architechture Dan Green Building Sebagai Upaya Pencapaian Sustainable Architecture. Jurnal UNPAND. Jurusan Arsitektur Fakultas Teknik Universitas Pandanaran.

https://jurnal.unpand.ac.id/index.php/dins ain/article/viewFile/90/87

5. Vicky Bertolini, Wisnumurti, Achfas Zacoeb. Aplikasi Value Engineering Pada Proyek Pembangunan Gedung (Studi Kasus Hotel Grand Banjarmasin). 
Narotama Jurnal Teknik Sipil. Volume 1 Nomor 2 November 2015.

6. Berman Taqwali Ega. Modul PLPG Teknik Pendingin. Universitas Negeri Yogjakarta. 2013

7. Andini Rizki, Utomo Christiono. Analisa Pengaruh Penerapan Konsep Green Building Terhadap Keputusan Investasi pada National Hospital Surabaya. Jurusan Teknik Sipil Institut Teknologi Sepuluh Nopember (ITS). JURNAL TEKNIK POMITS Vol. 3, No. 2, (2014) ISSN: 2337-3539.

8. Afify Ramez. Designing VRF Systems. ASHRAE Journal, June 2008 